\title{
Physico-chemical properties of municipal refuse in Lagos metropolis and cellulolytic activities of resident microorganisms associated with organic matter degradation
}

\author{
Adewale OGUNYEMI ${ }^{1}$, Olukayode AMUND ${ }^{1}$, Joy OKPUZOR ${ }^{2 *}$, Adesina \\ ADEIGA $^{3}$, Idika NNEOMA ${ }^{3}$, and Ahmed OMOWUNMI ${ }^{3}$ \\ ${ }^{I}$ Department of Botany and Microbiology, University of Lagos, Akoka Lagos, Nigeria. \\ 2 Department of Cell Biology and Genetics, University of Lagos, Akoka Lagos, Nigeria. \\ ${ }^{3}$ Nigerian Institute of Medical Research, Edmond Crescent Yaba, Lagos, Nigeria. \\ * Corresponding author, E-mail: joyokpuzor@yahoo.com, Phone: +234 8023065999
}

\begin{abstract}
This study investigated the activities of micro organisms involved in the degradation of organic matter in solid wastes and their potential to produce cellulolytic enzymes. Soil samples of decomposing waste piles were collected from four designated landfill sites in Lagos metropolis and analyzed for physicochemical properties, toxic heavy metal content and microbial populations. Findings revealed that the moisture content of the soils ranged from $7.6-10.0 \%$ in all the locations sampled. Ojota-Olusosun site had the highest organic matter content of $10.65 \%$. The highest viable bacterial counts were $28.2 \pm 3.0 \times 10^{6} \mathrm{cfu} / \mathrm{g}$ while fungi were $47.0 \pm 4.0 \times 10^{4} \mathrm{cfu} / \mathrm{g}$ respectively. A similar pattern was observed for phosphate and chloride levels while some heavy metals were also detected in varying and high amounts. There was a significant positive correlation at $5 \%$ level between fungal viable counts and phosphate ion while a significant negative correlation was observed for total hydrocarbon. The bacteria associated with the soil samples were identified as Escherichia coli, Bacillus spp, Klebisella spp, Micrococcus spp. and Acinetobacter spp while the resident fungal species were mostly the Aspergillus spp and an isolate identified as Mucor spp. The moulds were found to be capable of utilising lignin and cellulosic substrates for growth and for production of cellulolytic enzymes. Results from this study suggest that such micro organisms could be useful in bioconversion of cellulosic substrates and solid wastes to cellulolytic enzymes for industrial processes.
\end{abstract}

(C) 2010 International Formulae Group. All rights reserved.

Keywords: Solid wastes, Landfills, Heavy metals, Bacteria, Cellulolytic enzymes, Fungi.

\section{INTRODUCTION}

The management of solid wastes has been a major challenge of urbanization globally. Boadi \& Kuitunen (2003) reported that population growth and uncontrolled urbanisation in Accra Ghana, generates large quantities of wastes daily which exerts much pressure on an over-strained solid waste management system. It has been reported that approximately 4 million tonnes of municipal solid waste (MSW) is generated annually in the city of Lagos and this includes about 0.5 million of untreated industrial waste (Kofoworola, 2007) (Figure 1).

Land filling is considered a reliable and cost-effective method of solid waste management and disposal in developing 


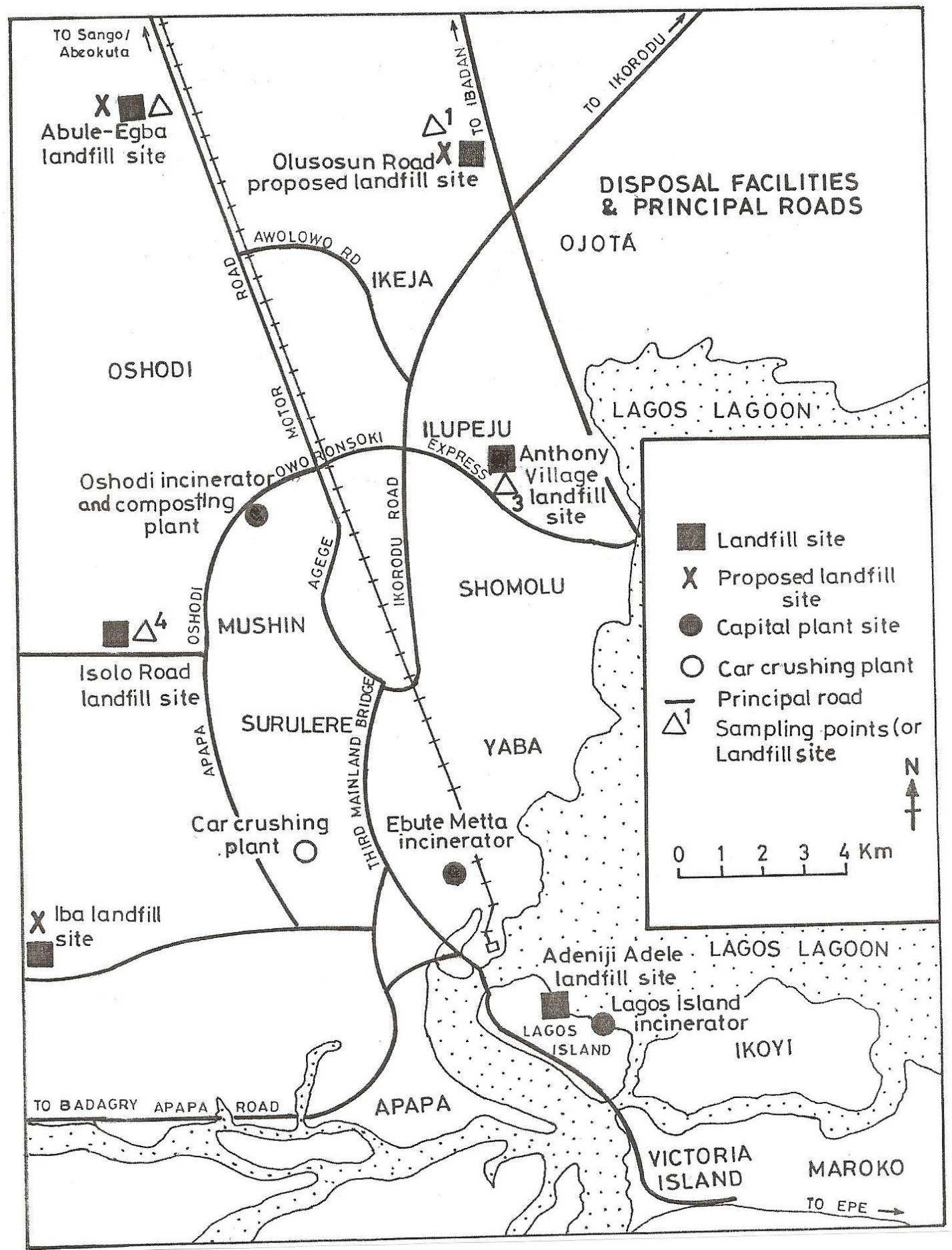

Figure 1: Map of the Lagos City showing Landfill sites and sampling points. 
countries due to availability and accessibility to vast acreages of idle land. These landfills sites are simply open but controlled dumpsites (Johanessen et al., 1999). Landfill has been reported to be the cheapest known method of final disposal of solid wastes generated by human activities (Leton and Omotosho, 2004). Open waste dump systems have been reported to be widely used in Indonesia and Jatibarang landfill site, receives 650-700 tons of municipal waste per day from the city of Semarang, Central Java (Mangimbulude et al., 2009). Furthermore, Turkey has been reported to have over 2000 open dump sites in spite of efforts to change open dumping areas into sanitary landfills and to build modern recycling and composting facilities (Turan et al., 2009). On the other hand, although land filling and incineration are popular ways to deal with biowaste, they are both reported to cause negative environmental effects such as the use of valuable land and production of dangerous gases (van Wyk, 2001).

However, the structural components of cells, cellulose and hemicellulose, make biowaste very susceptible for bioproduct development and biowaste offers biotechnology an opportunity to assist in maintaining environmental quality (van Wyk 2001).

Engineered sites in Africa receive various types of refuse including food, garden wastes, paper products, packaging materials, wood shavings, leather and textiles (Barlaz et al., 1989). Landfill wastes are heterogeneous and biological degradation takes place within its microenvironment (Ham et al., 1993). However, paper and paper-related products are the chief constituents of municipal solid wastes, averaging about 40 per cent of the total mass (Barlaz et al., 1990). These paper products contain holocellulose comprising of cellulose and hemicelluloses, which are complexed with lignin to form lignocellulose.

Degradation of lignocellulose is highly essential for the operation of the global carbon cycle (Tuomella et al., 2000). Tremendous quantities of cellulosic materials exist in municipal wastes around the Lagos metropolis. Bioconversion of these cellulosic materials particularly enzyme hydrolysis, had assumed great potential from the point of view of waste management and isolation of suitable microbial strains that could become useful as sources of hydrolytic enzymes. The enzymatic degradation of waste cellulose by fungal enzymes has been suggested as a feasible alternative for the conversion of lignocelluloses into fermentable sugars and biofuel ethanol (Oksanen et al., 2000).

The objective of this study is to investigate the activity of the micro organisms involved in the degradation of organic matter in solid wastes and their potential to produce cellulolytic enzymes which could be used for possible industrial application.

\section{MATERIALS AND METHODS \\ Collection of samples and Microbiological analyses}

Samples were collected from four major landfill sites within the Lagos metropolis in screw cap bottles for microbiological analyses while polyethylene bags were used samples designated for physicochemical analysis. The sampling points were Ojota-Olusosun, Abule Egba, Anthony Village and lsolo in Lagos metropolis. Appropriate dilutions of soil suspensions were aseptically spread on various selective and non-selective media for enumeration and isolation of various microorganisms. Nutrient agar plates were used for total bacterial count while moulds were enumerated on potato dextrose agar plates. Bacterial isolates were isolated from growths on various media and were identified by the conventional taxonomic techniques as described by Buchanan and Gibbons (1974) and fungal colonies according to the procedures described by Gilman (1959), Alexopoulus (1962) and Harrigan and McCance (1976). The isolates were tested for their ability to utilize cellulose, hemicellulose (xylan), cellobiose and carboxymethylcellulose). 


\section{Determination of physicochemical parameters in dumpsite soils}

The physicochemical properties of the soils were determined by standard methods. Soil $\mathrm{pH}$ was measured electrometrically with Orion 3 Star bench top $\mathrm{pH}$ meter. Moisture content and total hydrocarbon content were determined by gravimetric method. Cation Exchange Capacity (CEC) was determined by Titrimetry with EDTA. Olsen method using the UV Spectrophotometer was adopted for determining available phosphate-phosphorus. Finally, Potassium and heavy metals were determined by Atomic Absorption Spectrophotometry using Perkin-Elmer Analyst 200.

\section{Assay of cellulolytic enzymes}

Fungal isolates were grown in mineral salts medium containing carboxymethylcellulose $(2.0 \% \mathrm{w} / \mathrm{v})$ as the sole carbon source using the method of Pyc et al. (1977). Cellulose activity was determined in culture filtrates using xylan, cellobiose and carboxymethylcellulose as substrates. The assay tubes contained the substrate solution $(2.0 \mathrm{ml}, 0.5 \% \mathrm{w} / \mathrm{v})$, acetate buffer $(2.0 \mathrm{M}, 2.0$ $\mathrm{m} 1)$ and the enzyme solution $(2.0 \mathrm{ml})$. The mixtures were incubated at $50{ }^{\circ} \mathrm{C}$ for $30 \mathrm{~min}$. Progressive changes in cellulase levels of fungal cultures were assayed on a daily basis for 12 days at 2 days interval. Reducing sugar released in the assay tubes, was measured by the Nelson-Somogyi method (Nelson, 1944). Enzyme activity was expressed as the amount of reducing sugar released per $\mathrm{ml}$ of culture filtrate.

\section{Statistical analysis}

ANOVA was used while Pearson's correlation coefficient was calculated and used to test the hypotheses that there is no correlation between population of cellulose utilizing fungi and each of the physiochemical variables.

\section{RESULTS}

\section{Physicochemical characteristics of soil samples}

Tables 1a shows the results of various physicochemical parameters including $\mathrm{pH}$, moisture content, total organic matter and carbon, total hydrocarbon content, cation exchange capacity and the levels of phosphorus, potassium, iron, chromium, cadmium, nickel and zinc. High levels of these physical and chemical parameters were observed in the soil samples.

\section{Microbial composition of soil samples from decomposing refuse}

Table 1b shows the physicochemical parameters and population levels of bacteria and fungi in the soil samples collected from the decomposed refuse dumpsites. OjotaOlusosun site had the highest viable bacteria counts of $28.2 \pm 3.0 \times 10^{6} \mathrm{cfu} / \mathrm{g}$ and fungi 47.0 $\pm 4.0 \times 10^{4} \mathrm{cfu} / \mathrm{g}$ respectively. Distinct bacterial and fungal strains were isolated and characterized on the basis of their cultural, biochemical and physiological properties. The bacteria identified were Escherichia coli, Bacillus spp, Klebisella spp, Micrococcus spp. and Acinetobacter spp. Furthermore, the fungal isolates identified were Aspergillus niger (strains 1 and 2), Aspergillus flavus, Aspergillus fumigatus, Aspergillus wentii, Mucor spp. All the fungal isolates were observed to be cellulolytic while the bacteria were non-cellulolytic except for Acinetobacter spp. which was mildly cellulolytic. Correlation coefficient analysis relating the population of cellulose-utilizing fungi to soil physico-chemical parameters were computed as +0.10, +0.86, +0.19, +0.97 and +0.34 respectively.

These sample correlation coefficients at $5 \%$ level seem to suggest that the population of cellulose-utilizing fungi is weakly positively correlated with moisture content, total organic matter, total carbon and potassium. However, the population of these cellulose-utilizing fungi shows a significant positive correlation with phosphate ion.

Thus phosphate appears to be the most important factor in the soil samples affecting population counts. Negative correlation coefficients were obtained for cation exchange capacity, total hydrocarbon and chloride given as $-0.01,-0.91-0.30$ respectively. The sample correlation coefficients seem to indicate no. 
Table 1a: Physicochemical parameters of soils from refuse dumpsites.

\begin{tabular}{llcccc}
\hline Sites & $\begin{array}{c}\text { Depth } \\
(\mathbf{c m})\end{array}$ & $\mathbf{p H}$ & $\begin{array}{c}\text { Moisture } \\
\text { Content } \\
(\boldsymbol{\%})\end{array}$ & $\begin{array}{c}\text { Total Organic } \\
\text { Matter } \\
(\boldsymbol{\%})\end{array}$ & $\begin{array}{c}\text { Total } \\
\text { Carbon } \\
(\%)\end{array}$ \\
\hline Ojota & $0-15$ & 7.47 & 9.10 & 9.20 & 5.30 \\
& $15-30$ & 7.50 & 10.90 & 12.10 & 7.00 \\
\hline Abule Egba & Mean & 7.49 & 10.00 & 10.65 & 6.15 \\
& $0-15$ & 7.76 & 8.10 & 3.20 & 1.90 \\
& $15-30$ & 7.86 & 7.10 & 5.50 & 3.20 \\
\hline Anthony Village & Mean & 7.81 & 7.60 & 4.35 & 2.55 \\
& $15-15$ & 7.62 & 7.70 & 6.20 & 3.60 \\
\hline Isolo & $15-30$ & 7.51 & 9.40 & 7.90 & 4.70 \\
& Mean & 7.57 & 8.55 & 7.05 & 4.15 \\
\hline
\end{tabular}

Table 1b: Physicochemical parameters and microbial populations of soils from refuse dumpsites.

\begin{tabular}{|c|c|c|c|c|c|c|c|c|}
\hline Sites & $\begin{array}{l}\text { Depth } \\
(\mathrm{cm})\end{array}$ & $\begin{array}{l}\text { Available } \\
\text { PO4 } \\
\text { (mg/kg) }\end{array}$ & $\begin{array}{l}\text { Potassium } \\
\text { Content } \\
(\mathrm{mg} / \mathrm{kg})\end{array}$ & $\begin{array}{l}\text { Chloride } \\
\text { Level } \\
(\mathrm{mg} / \mathrm{kg})\end{array}$ & $\begin{array}{c}\text { Total } \\
\text { HC } \\
\text { Content } \\
\text { (mg/kg) } \\
\end{array}$ & $\begin{array}{c}\text { Cation } \\
\text { Exchange } \\
\text { Capacity } \\
\text { (meg/100g) }\end{array}$ & $\begin{array}{r}\text { Bacteria } \\
\text { (Colony } \\
\text { forming } \\
\text { Units/g) } \\
\end{array}$ & $\begin{array}{c}\text { Fungi } \\
\text { (Colony } \\
\text { forming } \\
\text { Units/g) }\end{array}$ \\
\hline \multirow[t]{3}{*}{$\overline{\text { Ojota }}$} & $0-15$ & 256.00 & 1120.40 & 921.50 & 0.18 & 12.30 & $28.2 \pm 3.0$ & $47.0 \pm 4.0$ \\
\hline & $5-30$ & 198.50 & 1192.20 & 986.90 & 0.32 & 6.70 & & \\
\hline & Mean & 227.30 & 1156.30 & 954.20 & 0.25 & 14.50 & & \\
\hline Abule & $0-15$ & 213.70 & 1184.60 & 534.70 & 0.41 & 4.90 & $18.0 \pm 4.0$ & $34.6 \pm 5.2$ \\
\hline \multirow[t]{2}{*}{ Egba } & $15-30$ & 170.40 & 1306.30 & 785.50 & 0.19 & 7.50 & & \\
\hline & Mean & 192.05 & 1245.45 & 660.60 & 0.30 & 6.20 & & \\
\hline Anthony & $0-15$ & 149.10 & 1158.10 & 872.10 & 0.65 & 1.70 & $125 \pm 2.0$ & $23.2 \pm 3.5$ \\
\hline \multirow[t]{2}{*}{ Village } & $15-30$ & 206.40 & 1088.00 & 206.4 & 0.23 & 24.90 & & \\
\hline & Mean & 177.75 & 1123.05 & 539.25 & 0.44 & 18.30 & & \\
\hline \multirow[t]{3}{*}{ Isolo } & $0-15$ & 138.00 & 1168.10 & 887.80 & 0.54 & 11.20 & $9.5 \pm 1.5$ & $12.5 \pm 5.0$ \\
\hline & $15-30$ & 124.00 & 1119.80 & 901.80 & 0.29 & 12.30 & & \\
\hline & Mean & 131.00 & 1143.95 & 894.80 & 0.42 & 1.75 & & \\
\hline
\end{tabular}

linear association between cellulose-utilizing fungi and cation exchange capacity and chloride, although a significant negative linear association exists with total hydrocarbon Table 2 shows the concentration of heavy metals obtained from the refuse dumpsites. Of all the toxic elements measured, the highest average concentration of these metals ranged from $926.6-954.6 \mathrm{mg} / \mathrm{kg}$ for Iron, Lead was 125.4-758.3 $\mathrm{mg} / \mathrm{kg}, \quad$ Nickel 28.55-286.35 $\mathrm{mg} / \mathrm{kg}$ and Zinc $110.05-174.65 \mathrm{mg} / \mathrm{kg}$ in soils while the least average concentration of 7.78$13.2 \mathrm{mg} / \mathrm{kg}$ was recorded for cadmium.

Production of cellulolytic enzymes by fungal isolates

Tables 3-5 show the progressive release of reducing sugars from three cellulosic substrates by culture filtrates of $A$. niger (strain 1 and 2), A. flavs (strain $1 \& 2$ ), fumigatus, A. wentii, Mucor spp. and Aspergillus spp. Enzyme activities recorded for all the strains using cellobiose as substrate were generally higher than those for xylan and carboxymethylcellulose. Furthermore, enzyme activities in culture filtrates increased with time and the age of the culture. Maximum activity peaks were observed between day 2 and 6 as a general pattern, and also between day 8 and 10 of incubation in some strains.

\section{DISCUSSION}

Soil is the primary recipient of solid wastes (Nyle and Ray, 1999). Millions of tons of wastes from a variety of sources like industrial, domestic and agricultural find their ways into the soil. 
Table 2: Heavy metal contents of the soils from refuse dumpsites.

\begin{tabular}{lccccccc}
\hline \multirow{2}{*}{ Sites } & \multicolumn{7}{c}{ Soil Parameter $($ Heavy metal) $\mathbf{~ m g} / \mathbf{k g}$} \\
\cline { 2 - 8 } Ojota & Depth $(\mathbf{c m})$ & $\mathbf{F e}$ & $\mathbf{P b}$ & $\mathbf{Z n}$ & $\mathbf{N i}$ & $\mathbf{C d}$ & $\mathbf{C r}$ \\
& $0-15$ & 929.0 & 130.1 & 156.6 & 130.1 & 15.5 & 116.3 \\
& $15-30$ & 941.4 & 214.6 & 178.6 & 214.6 & 10.8 & 107.8 \\
\hline Abule Egba & Mean & 935.2 & 172.4 & 167.6 & 172.4 & 13.2 & 112.1 \\
& $0-15$ & 926.7 & 216.5 & 178.1 & 36.6 & 15.6 & 125.4 \\
& $15-30$ & 926.6 & 34.3 & 172.8 & 21.1 & 9.5 & 95.6 \\
\hline Anthony Village & Mean & 926.7 & 125.5 & 175.5 & 28.9 & 12.6 & 110.5 \\
& $0-15$ & 964.2 & 470.4 & 176.3 & 176.3 & 7.2 & 176.1 \\
& $15-30$ & 954.0 & 132.2 & 169.9 & 169.9 & 8.3 & 173.2 \\
\hline Isolo & Mean & 959.1 & 301.3 & 173.1 & 173.1 & 7.8 & 174.7 \\
& $0-15$ & 946.4 & 747.5 & 162.1 & 53.8 & 8.3 & 136.6 \\
& $15-30$ & 943.6 & 769.1 & 162.0 & 62.5 & 7.3 & 135.8 \\
& Mean & 945.0 & 758.3 & 162.1 & 58.2 & 7.8 & 136.2 \\
\hline
\end{tabular}

Table 3: Release of reducing sugar from Xylan by enzymes in the culture filtrate of cellulosic substrates of A. niger (strain 1\&2), A. flavus (strain 1\&2), A. fumigatus, A. wentii, Mucor spp. and Aspergillus spp.

\begin{tabular}{lcccccccc}
\hline & \multicolumn{7}{c}{ XYLAN(mg/ml reducing sugar $\mathbf{~ 1 0}^{-3}$ ) } \\
\cline { 2 - 9 } Days & A nig1 & A nig2 & A flav1 & A flav2 & A fum & A wen & Mu spp & A spp \\
\hline 2 & 388 & 392 & 351 & 438 & 320 & 355 & 357 & 343 \\
4 & 275 & 290 & 608 & 390 & 588 & 675 & 298 & 267 \\
6 & 743 & 334 & 657 & 676 & 661 & 678 & 287 & 273 \\
8 & 298 & 275 & 682 & 384 & 302 & 277 & 253 & 285 \\
10 & 547 & 266 & 277 & 419 & 741 & 313 & 225 & 265 \\
12 & 256 & 277 & 256 & 647 & 468 & 277 & 234 & 255 \\
\hline
\end{tabular}

A nig1 =Aspergillus niger $1 ; \mathrm{A}$ nig2 = Aspergillus niger $2 ; \mathrm{A}$ flav1 $=$ Aspergillus flavus $1 ;$ A flav2 = Aspergillus flavus $2 ; \mathrm{A}$ fum $=$ Aspergillus fumigatus; $\mathrm{A}$ wen $=$ Aspergillus wentii Mu spp = Mucor spp; A spp = Aspergillus spp.

Table 4: Release of reducing sugar from Cellobiose by enzymes in the culture filtrate of cellulosic substrates of A. niger (strain 1\&2), A. flavus (strain 1\&2), A. fumigatus, A. wentii, Mucor spp. and Aspergillus spp.

\begin{tabular}{lcccccccc}
\hline & \multicolumn{7}{c}{ CELLOBIOSE $\left(\mathbf{m g} / \mathbf{m l}\right.$ reducing sugar $\mathbf{~ 1 0}^{-3}$ ) } \\
\cline { 2 - 8 } Days & A nig1 & A nig2 & A flav1 & A flav2 & A fum & A wen & Mu spp & A spp \\
\hline 2 & 288 & 258 & 207 & 293 & 200 & 230 & 239 & 226 \\
4 & 293 & 218 & 712 & 501 & 542 & 558 & 712 & 265 \\
6 & 794 & 452 & 823 & 786 & 761 & 662 & 270 & 696 \\
8 & 489 & 233 & 200 & 822 & 604 & 246 & 226 & 212 \\
10 & 753 & 222 & 233 & 717 & 748 & 438 & 242 & 423 \\
12 & 267 & 236 & 244 & 538 & 252 & 224 & 269 & 253 \\
\hline
\end{tabular}

A nig1 =Aspergillus niger $1 ;$ A nig $2=$ Aspergillus niger $2 ;$ A flav $1=$ Aspergillus flavus $1 ;$

A flav2 $=$ Aspergillus flavus $2 ; \mathrm{A}$ fum $=$ Aspergillus fumigatus; $\mathrm{A}$ wen $=$ Aspergillus wentii

$\mathrm{Mu} \mathrm{spp}=$ Mucor spp; $\mathrm{A} \mathrm{spp}=$ Aspergillus spp. 
Table 5: Release of reducing sugar from Carboxymethyl-cellulose by enzymes in the culture filtrate of cellulosic substrates of A. niger (strain 1\&2), A. flavus (strain 1\&2), A. fumigatus, A. wentii, Mucor spp. and Aspergillus spp.

\begin{tabular}{lcccccccc}
\hline & \multicolumn{7}{c}{ CARBOXYMETHYL-CELLULOSE $\left(\mathbf{m g} / \mathbf{m l}\right.$ reducing sugar $\mathbf{1 0}^{-\mathbf{3}}$ ) } \\
\cline { 2 - 9 } Days & $\boldsymbol{A}$ nig1 & A nig2 & A flav1 & A flav2 & A fum & A wen & Mu spp & A spp \\
\hline 2 & 298 & 282 & 191 & 341 & 215 & 215 & 220 & 205 \\
4 & 204 & 219 & 656 & 678 & 656 & 712 & 214 & 207 \\
6 & 481 & 202 & 326 & 572 & 793 & 654 & 200 & 743 \\
8 & 217 & 233 & 230 & 554 & 203 & 203 & 220 & 242 \\
10 & 212 & 227 & 200 & 645 & 611 & 205 & 209 & 210 \\
12 & 244 & 249 & 234 & 682 & 207 & 249 & 222 & 222 \\
\hline
\end{tabular}

A nig1 =Aspergillus niger $1 ;$ A nig2 = Aspergillus niger $2 ;$ A flav1 $=$ Aspergillus flavus $1 ;$

A Flav2 $=$ Aspergillus flavus 2; $\mathrm{A}$ fum $=$ Aspergillus fumigatus; $\mathrm{A}$ wen $=$ Aspergillus wentii

$\mathrm{Mu} \mathrm{spp}=$ Mucor spp; $\mathrm{A}$ spp $=$ Aspergillus spp.

These wastes end up interacting with the soil system thereby changing its physical and chemical properties (Piccolo and Mbagwu, 1997). As a consequence, the physicochemical properties of soils vary greatly. This in turn affects the "in situ" microbiology thereby having a profound implication on the biodegradation rate of organic matter. It is not surprising therefore that resident fungal species in contaminated soils were mainly the Aspergillus $s p$. Yang et al. (2009) had reported the adaptation of Aspergillus niger tolerating high concentration of heavy metals for bioleaching of fly ash. There is a dearth of published works on the physicochemical characteristics of solid wastes in the Nigerian environment. However, Lavani (1992) confirmed that much of the physical and chemical parameters in such wastes exceeded the limits specified by relevant environmental regulatory local and international agencies.

The analysis of the physical and chemical properties of the soil samples collected from the four dumpsites investigated, confirmed such anomalies. Iron and Lead levels were above the permissible level for soils as recommended by USEPA (1986). In a similar study, Kabata-Pendias and Pendias (1994) reported a lower range 30-300 $\mathrm{mg} / \mathrm{kg}$ for both metals. Nickel, chromium, cadmium and zinc were found to be below the critical permissible concentrations in soils.
The higher population counts of bacteria and fungi at the Ojota-Olusosun sampling site may underscore a more conducive environment for microbial proliferation and biological activity leading to a more rapid decomposition of organic matter at this dumpsite. However, the bulk of cellulolytic activities are attributable to the fungal populations. This is without prejudice to the possible existence of cellulose-decomposing bacteria at these sites that escaped detection in this study because they could occur in low numbers.

The enzymatic hydrolysis of cellulosic materials has been widely studied (Okafoagu and Nzelibe, 2006; Wen et al., 2005 ; Foyle et al., 2007). The production of sugars, biofuels and single cell protein are potential uses of such hydrolysis. Studies on fungal growth on cellulose and hemicellulose waste material have been carried out using sawdust, paper, filter paper, corn bran and straw. However, the rate of hydrolysis of cellulosic materials is still relatively slow and much of the present work in this area is aimed at increasing these rates. In this wise, the cellulolytic activities of the fungal strains were obtained in this study using shake-flask cultures leading to a relatively higher rate of cellulase and hemicellulase activities. Similar results were reported by Pyc et al. (1977). Cellulosic biomass abundantly provided by nature is a renewable resource for production of fuels and other useful products. 
This study therefore reports that decomposing solid wastes may provide a reliable source of micro organisms that could be used in the bioconversion of cellulosic substrates and as a venerable source of cellulolytic enzymes for industrial application.

\section{REFERENCES}

Alexopoulus CJ. 1962. Introduction to Mycology ( $2^{\text {nd }}$ edn). John Wiley and Sons Inc: New York.

Barlaz MA, Ham RK, Schaefer DM. 1989. Mass-balance analysis of aerobically decomposed refuse. J. Environ. Eng., 115: $1088-1102$.

Boadi KO, Kuitunen M. 2003. Municipal solid waste management in the accra metropolitan Area, Ghana. The Environm. 23(3): 211-218.

Buchanan RE, Gibbons NE. 1974. Bergey's Manual of Determinative Bacteriology. The Williams and Wilkins Company: Baltimore; 1246.

Foyle T, Jennings L, Mulcahy P. 2007. Compositional analysis of lignocellulosic materials: Evaluation of methods used for sugar analysis of waste paper and straw. Bioresource Technol., 98: 3026-3036.

Gilman SC. 1959. A Manual of Soil Fungi $\left(2^{\text {nd }}\right.$ edn). The Iowa State University Press: Ames, Iowa, U.S.A.

Ham RK, Norman MR, Fritschel PR. 1993. Chemical characterization of Fresh Kills Landfill Refuse and Extracts. J. Environ. Eng., 119: 1176-1195.

Harrigan WF, McCance ME. 1976. Laboratory Methods in Food and Dairy Microbiology. Academic Press: London, New York, San Francisco.

Johanessen LM, Boyer G. 1999. Observations of Solid waste Landfills in Developing Countries Africa, Asia and Latin America: The World Bank: Washington DC.

Kabata-Pendias A, Pendias H. 1984. Trace elements in soils and plants. CRC Press Boca Raton Fla., 85:107-129.
Kofoworola. 2007. Recovery and recycling practices in municipal solid waste management in Lagos, Nigeria. Waste Mngmt., 27(9): 1139-1143.

Lavani Incorporation. 1992. Waste generation and composition of domestic wastes in Lagos State. Report on design and operation of Isolo landfill site submitted to the Lagos Statewaste disposal board, Nigeria.

Leton TG, Omotosho O. 2004. Landfill operations in the Niger delta region of Nigeria. Engr. Geol., 73(1-2): 171-177.

Mangimbulude JC, van Breukelen BM, Krave AS, van Straalen NM, Röling WFM. 2009. Seasonal dynamics in leachate hydrochemistry and natural attenuation in surface run-off water from a tropical landfill. Waste Mngmt., 29(2): 829-838.

Nelson N. 1944. A Photometric adaptation of the Somogyi method for the determination of glucose. J. Biol. Chem., 153: $375-380$.

Nyle CB, Ray RN. 1999. The Nature and Properties of Soils (12 ${ }^{\text {th }}$ edn). United States of America; 743-785.

Okafoagu CU, Nzelibe HC. 2006. Effect of acid hydrolysis of Garcinia kola (bitter kola) pulp waste on the production of CM-cellulase and glucosidase using Aspergillus niger. Afr. J. Biotechnol., 5: 819-822.

Oksanen TJ, Pere I, Paavilainen I, Buchert I, Viikari I. 2000. The enzymatic degradation of waste cellulose by fungal enzymes. J. Biotechnol., 78: 39-48.

Piccolo A, Mbagwu JSC. 1997. Exogenous Humic Substances as Conditions for the Rehabilitation of Degraded Soils. Agro. Foods Industry Hi-Tech.

Pyc R, Fiechter A, Galas E. 1977. The production of cellulolytic enzymes by fungal cultures. European J. Appl. Microbiol., 4: 151-158.

Tuomella M, Vickman M, Hatakka A, Havaara M. 2000. Biodegradation of lignin in compost environment: a 
review. Bioresource Technol., 72: 109183.

Turan NG, Çoruh S, Akdemir A, Ergun ON. 2009. Municipal solid waste management strategies in Turkey. Waste Mngmt., 29(1): 465-469.

United States Environmental Protection Agency. 1986. Test Methods of Evaluation for Solid Waste. USEPA S/W 846 USEPA: Washington DC.

van Wyk JPH. 2001. Biotechnology and the utilization of biowaste as a resource for bioproduct development. Trends Biotchnol., 19(5): 172-177.

Wen Z, Liao W, Chen S. 2005. Production of cellulase by Trichoderma reesei from dairy manure. Bioresource Technol., 96: 491-499.

Yang J, Wang U, Wang Q, Wu T. 2009. Heavy metal extraction from municipal solid waste incineration fly ash using adapted metal tolerant Aspergillus niger. Bioresource Technol., 100: 254-260. 